\title{
Tracking Triploid Mortalities Of Eastern Oysters Crassostrea virginica In The Virginia Portion Of The Chesapeake Bay
}

\author{
Eric Guevelou \\ Virginia Institute of Marine Science \\ Ryan Carnegie \\ Virginia Institute of Marine Science \\ JA Moss \\ Virginia Institute of Marine Science \\ Karen Hudson \\ Virginia Institute of Marine Science \\ Kimberly S. Reece \\ Virginia Institute of Marine Science
}

See next page for additional authors

Follow this and additional works at: https://scholarworks.wm.edu/vimsarticles

Part of the Aquaculture and Fisheries Commons, and the Marine Biology Commons

\section{Recommended Citation}

Guevelou, Eric; Carnegie, Ryan; Moss, JA; Hudson, Karen; Reece, Kimberly S.; Rybovich, Molly M.; and Allen, Standish K. Jr., "Tracking Triploid Mortalities Of Eastern Oysters Crassostrea virginica In The Virginia Portion Of The Chesapeake Bay" (2019). VIMS Articles. 1333.

https://scholarworks.wm.edu/vimsarticles/1333 


\section{Authors}

Eric Guevelou, Ryan Carnegie, JA Moss, Karen Hudson, Kimberly S. Reece, Molly M. Rybovich, and Standish K. Allen Jr. 


\title{
TRACKING TRIPLOID MORTALITIES OF EASTERN OYSTERS CRASSOSTREA VIRGINICA IN THE VIRGINIA PORTION OF THE CHESAPEAKE BAY
}

\author{
ERIC GUÉVÉLOU,“ RYAN B. CARNEGIE, JESSICA MOSS SMALL, KAREN HUDSON, \\ KIMBERLY S. REECE, MOLLY M. RYBOVICH AND STANDISH K. ALLEN JR. \\ Virginia Institute of Marine Science, College of William \& Mary, P.O. Box 1346, Gloucester Point, \\ Virginia 23062
}

\begin{abstract}
Since 2012, aquacultured eastern oysters Crassostrea virginica have been reported by oyster farmers to display mortality approaching $30 \%$, and in some cases $85 \%$, in areas of the lower Chesapeake Bay, VA. Based on accounts from industry, this mortality has typically affected 1-y-old oysters between May and early July, and has tended to occur in triploid oysters, which represent the vast bulk of production in the area. During this period, samples submitted for pathology have not revealed the presence of major pathogens as a cause. In 2015, to gain deeper insight into this mortality and determine whether specific sites, ploidy condition, or genetic lines were affected, oyster seed commercially produced in early 2014 were obtained from four lines, one diploid (2N DEBY) and three triploid (3N DEBY, 3N hANA, and 3N Northern). These lines were deployed in July 2014 at aquaculture farms at five Chesapeake Bay locations: Locklies Creek and Milford Haven on the western shore, and Pungoteague Creek, Nassawadox Creek, and Cherrystone Creek on the Eastern Shore. During this study, mortality was observed to peak in June at most sites, reaching a mean mortality across all tested lines of $17.0 \%$ and a cumulative mortality for the study period of $32.0 \%$ at Nassawadox Creek, the site most severely affected by mortality that followed the expected early summer mortality pattern. Interval mortality at all sites decreased to under 5\% after June, but cumulative levels for the study period reached from $8.8 \%$ to $18.6 \%$ even at the sites least affected by mortality. This represents a high level of mortality given the documented absence of material involvement by major oyster pathogens such as Hapolosporidium nelsoni and Perkinsus marinus. Infiltration of gill tissues by hemocytes, observed in up to $33 \%$ of individuals at Nassawadox Creek coincident with the increase in mortality, was the only pathology observed. Harmful algal blooms were not associated with the mortality, nor were abnormal temperatures or salinities. There was no clear relationship of mortality to oyster genetic heritage, although there was variability in susceptibility among oyster lines and interactions between lines and specific sites. At some locations and in comparison with diploids, triploid oysters appeared to be more susceptible to mortality. Mortality in triploids was coincident with the timing of peak gametogenic development in diploids. Given the lack of involvement by major pathogens and the possible association of mortality with oyster gametogenesis, future work should seek to better understand the suite of environmental stressors potentially impacting cultured oysters in these systems and their interactions with the physiology and energetics of these animals.
\end{abstract}

KEY WORDS: Crassostrea virginica, mollusc health, marine disease, summer mortality, aquaculture-environment interactions, polyploidy

\section{INTRODUCTION}

The eastern oyster Crassostrea virginica has been plagued by two major pathogens through much of its North American distribution, the protozoan parasites Perkinsus marinus (Mackin et al. 1950) and Haplosporidium nelsoni (Haskin et al. 1966), which cause the diseases known as dermo and MSX, respectively. A third pathogen, Roseovarius crassostreae, the bacterial agent of Roseovarius oyster disease or ROD, has also contributed to aquaculture losses in the Northeast since the 1980s (Boettcher et al. 1999, Boettcher et al. 2005). In the MidAtlantic region of the United States, disease impacts from dermo and MSX in combination with other factors such as overfishing and habitat loss have led to the serious decline of wild $C$. virginica harvests and greatly diminished an extensive aquaculture industry that dated back to the 1800s (Brooks 1891, Haven et al. 1978, Andrews 1988, Barber \& Mann 1991). During the last decade in the Chesapeake Bay, an oyster aquaculture industry reemerged with an emphasis on the intensive culture of fast-growing stocks genetically selected for resistance to these pathogens (Ragone Calvo et al. 2003, FrankLawale et al. 2014, Dégremont et al. 2015). Use of polyploidy (Stanley et al. 1981) has produced further advantages; triploid

*Corresponding author. E-mail: eguevelou@vims.edu DOI: $10.2983 / 035.038 .0110$ oysters grow faster than their diploid counterparts as a result of their reduced fecundity (Allen \& Downing 1986, 1990, Nell 2002), present a greater heterozygosity (Hawkins et al. 2000), and a better energy allocation toward growth rather than gametogenesis (Nell \& Maguire 1998, Garnier-Géré et al. 2002). These same advantages have been thought to confer triploids with increased disease resistance and, subsequently, better survival than diploids (Allen \& Downing 1986, Normand et al. 2008, Samain \& McCombie 2008, Dégremont et al. 2012). Although an advantage of triploids over diploids is not always clear (Goulletquer et al. 1996, Cheney et al. 2000, Pernet et al. 2010, Callam et al. 2016), triploid use is typical in intensive aquaculture in the Chesapeake Bay region today (Hudson 2017). For example, of 35.4 million cultured oysters sold in Virginia in 2015, more than $90 \%$ were triploid (Hudson \& Murray 2016).

Since at least 2012, shellfish growers in the Virginia portion of the Chesapeake Bay have observed annual mortality events that have typically peaked between May and June and resulted in the reported loss of roughly $30 \%$ of their market or just under market-sized oysters. These events have been unusual in that they have not been associated with any of the well-documented regional pathogens, such as Haplosporidium nelsoni or Perkinsus marinus, or with Haplosporidium costale, the agent of SSO disease that is found in higher salinity environments (Wood \& 
Andrews 1962), nor are they consistently associated with other signs of pathology (Carnegie, unpublished data). Affected farms have primarily been located in small Chesapeake Bay tributaries along the lower western coast of the Virginia Eastern Shore region (i.e., the bayside Eastern Shore). Although crop loss in prior years generally has been manageable by the industry, mortality in the spring of 2014 was extraordinary in that it reportedly reached $85 \%$ at some farms, prompting intensive examination of factors potentially contributing to the events. These events have come to be referred to as "triploid mortality," eventhough this may be a misnomer, because most farms in this area grow only triploids. It has not been clear that triploids are actually more susceptible to the mortality events than diploids.

This work describes an initial experimental investigation into early summer triploid mortality in the Chesapeake Bay to better understand the timing, course, and potential causes of the oyster mortality. It addresses three emerging questions: first, whether oysters grown at bayside Eastern Shore sites may be more susceptible to mortality than those grown at other sites; second, whether triploid oysters are more susceptible than diploids to mortality; and third, whether specific triploid oyster lineages are more susceptible than others to mortality. The latter question emerged from anecdotal reports that " $3 \mathrm{~N}$ Northern" triploids made using Virginia tetraploids produced by the VIMS Aquaculture Genetics and Breeding Technology Center (VIMS ABC) and a proprietary line of diploid oysters originating from Maine (hereafter, the ME line) showed higher mortality than "3N DEBY" triploids produced using the same Virginia tetraploids and the DEBY line of diploids of MidAtlantic origin (Ragone Calvo et al. 2003).

This study was undertaken as a rapid institutional response to the very high 2014 oyster mortality, and because it was developed and implemented rapidly, some elements of its design were not ideal. First, the timing of the response was awkward because it commenced after the report of the 2014 mortalities without benefit of a remaining spawning season to produce controlled crosses for the following year. Second, area farms had limited sources of younger seed with which to initiate the study, most retaining the so-called " $3 \mathrm{~N}$ Northern triploids." Nonetheless, important insight was generated into the previous questions that set the stage for what will clearly be more investigations into "triploid mortality."

\section{MATERIALS AND METHODS}

\section{Source of Seed}

The study began in July 2014, after the bulk of mortalities had been reported. The objective was to set up an experiment for the following year, 2015. One of the key factors in "triploid mortality" appeared to be that 1-y-old oysters approaching market size (around 3 inches, $76 \mathrm{~mm}$ ) were most vulnerable. Oysters of such size in May would have needed to be produced from spawns very early in the previous year. It was clearly not possible by July 2014, therefore, to produce new seed that would reach appropriate size by May 2015. To conduct the study immediately, so that data could be collected in the expected window of triploid mortality, seed was obtained that was produced earlier in the spring of 2014 by commercial hatcheries. The identities of these hatcheries are coded here to maintain confidentiality. From Hatchery A, two lines of triploid seed were obtained: $3 \mathrm{~N}$ DEBY and $3 \mathrm{~N}$ hANA. Each was produced from diploid disease-resistant lines (DEBY or hANA) crossed to a single VIMS ABC tetraploid line (GEN). Diploid $2 \mathrm{~N}$ DEBY seed was obtained for use as control from Hatchery A. From Hatchery B, a third test group of triploids was acquired that were produced by crossing a proprietary diploid Maine line with the VIMS ABC tetraploid line (GEN) to create a $3 \mathrm{~N}$ Northern cross.

\section{Experimental Design and Study Area}

Approximately 6,000 seed oysters from each of the four test lines (3N DEBY, 3N hANA, 3N Northern, and 2N DEBY) were used in the experiment. At deployment as juvenile oysters in July 2014, 25 individuals from each line were sampled to measure shell height (distance from hinge to bill) and total mass, and an additional 15 oysters per line were processed for histopathology for an initial disease screening (see Histopathology). The 25 individuals from each line were shucked, and a gill sample from each was processed for flow cytometry to assess ploidy by comparing relative DNA content to that from a diploid gill as a standard. Nuclear DNA was stained with the fluorescent dye DAPI and processed via techniques described by Allen and Bushek (1992). If a presumed triploid group was less than $100 \%$ triploid at initial sampling, 25 additional oysters from that group were analyzed. This occurred only for seed samples taken from the $3 \mathrm{~N}$ Northern line.

The abovementioned four groups were distributed to growers at five sites in the Chesapeake Bay, VA. Sites included three on the bayside Eastern Shore, Pungoteague Creek, Nassawadox Creek, and Cherrystone Creek; and two along the western shore of the Chesapeake Bay, Milford Haven and Locklies Creek (Fig. 1). All but the Locklies Creek site were at or near locations where mortality was reported in spring 2014

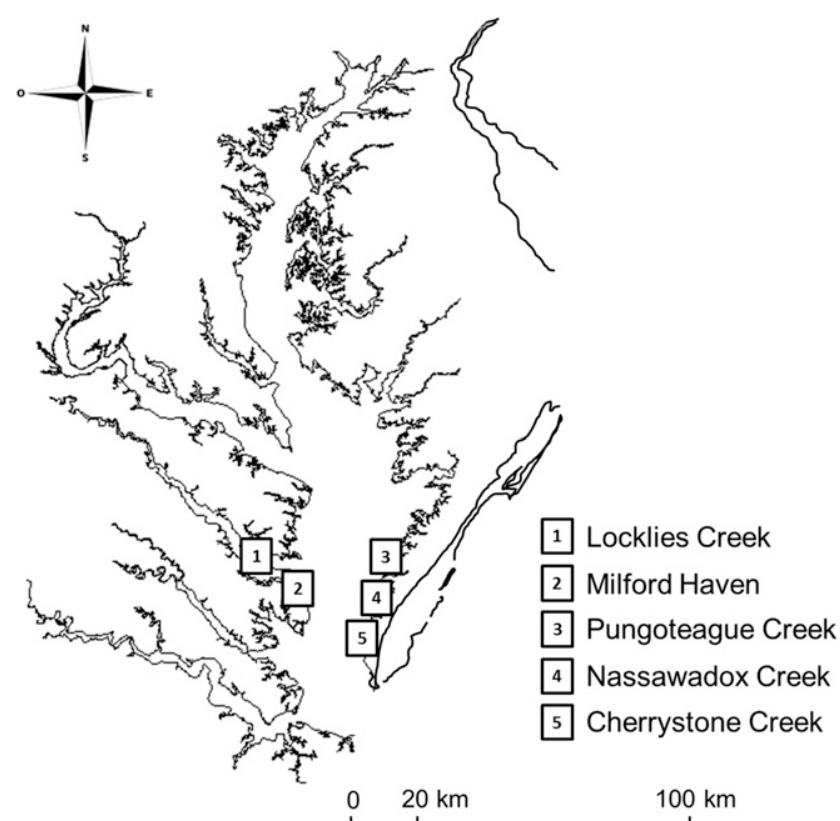

Figure 1. Map showing the location of five study sites around the lower Chesapeake Bay (USA). 
The bayside Eastern Shore creeks are characterized by low freshwater input and diurnal tidal action, with salinities ranging from 14 to $30 \mathrm{ppt}$ (Sanford et al. 2009). They are typically shallow and highly productive. Milford Haven is a narrow straight between Gwynn's Island and the mainland of Mathews County, VA, on the western shore of the Chesapeake Bay. The site is deeper and well flushed, atypical of other sites where oyster mortality was observed. Locklies Creek served as a control site because early season mortality had not been observed at that location. Commercial growers at each of these sites provided all grow-out gear and maintenance for the duration of the experiment. All growers were instructed to care for the experimental seed as they would for the commercial seed on their farms, for example by using similar stocking densities and cleaning cages at routine intervals. In December 2014, all seed was moved from inshore locations to deeper water at each site for overwintering.

From March 18 to April 22, 2015, lines at each site were assessed for survival after overwintering, and a subset of individuals from each line was collected for analyses. Dead oysters and those shorter than $2 \mathrm{~cm}$ in shell length were removed and up to 1,500 oysters per line were redeployed at each site. Three replicates of each redeployed line and the stocking density for each were set to promote optimal growth rate and survival over the growing period. The experiment was then sampled at three time points that were meant to encompass the timing of putative triploid mortality: between May 19 and June 3 (first sampling), between June 25 and July 9 (second sampling), and between August 3 and August 19, 2015 (final sampling). Between site visits, growers were asked to observe oysters regularly because sampling outside of scheduled visits was to be triggered if unusually high mortality was reported.

\section{Data Collection}

\section{Environmental Parameters}

Temperature and salinity were measured using dataloggers (HOBOware Conductivity Loggers; Onset, Bourne, MA) at each site beginning in November 2014.

\section{Microscopic and Quantitative Real-Time Polymerase Chain Reaction (qPCR) Analysis of Water Samples}

At each sampling period, two replicate $120-\mathrm{mL}$ water samples were collected from each site. The water samples were kept cool and in the dark until delivered to the laboratory. One of the replicate water samples was used for microscopic identification and enumeration of natural microalgal species present. Visual microscopic identification of dominant dinoflagellates, raphidophytes, and diatoms in water samples was accomplished by examination on an Olympus IX51 inverted microscope with a digital camera and CellSens 1.1 imaging software (Olympus Europa, Hamburg, Germany).

One hundred milliliters from the duplicate water samples was filtered through a $3-\mu \mathrm{m}$ Isopore membrane filter (Millipore Corp., Darmstadt, Germany) using sterile technique for DNA extraction and polymerase chain reaction (PCR) analysis. A "blank" sample (i.e., distilled water) was filtered alongside the environmental samples as a negative control to ensure that there was no sample-to-sample contamination or carry-over during processing. Filters were placed into 5-mL centrifuge tubes and frozen at $-20^{\circ} \mathrm{C}$ until processing for DNA analysis. DNA was extracted from the filters using the QIAamp Fast Stool Mini kit (Qiagen, Valencia, CA) following the manufacture's protocol with some modifications. An aliquot of $1 \mathrm{~mL}$ of InhibitEX Buffer was added to each 5-mL tube containing a filter. Tubes were vortexed at top speed for $1 \mathrm{~min}$ and incubated at $95^{\circ} \mathrm{C}$ for $5 \mathrm{~min}$ followed by vortexing for $15 \mathrm{sec}$. An aliquot of $75 \mu \mathrm{L}$ of proteinase $\mathrm{K}$ was added to each tube followed by vortexing for $15 \mathrm{sec}$, the addition of $1 \mathrm{~mL}$ of AL buffer with another $15 \mathrm{sec}$ of vortexing, and incubation at $70^{\circ} \mathrm{C}$ for $10 \mathrm{~min}$. An aliquot of $1 \mathrm{~mL}$ of ethanol was then added followed by vortexing again for $15 \mathrm{sec}$. The entire volume was applied to the QIAamp spin column $650 \mu \mathrm{L}$ at a time. The protocol for column washing and DNA elution was followed as written. DNA was stored at $-20^{\circ} \mathrm{C}$ until PCR assays were to be performed.

Quantitative real-time PCR assays targeting "harmful" algal species Alexandrium monilatum, Margalefidinium polykrikoides (previously Cochlodinium), Karlodinium veneficum, Luciella spp., Pfiesteria piscicida, Pseudopfiesteria shumwayae, and Prorocentrum minimum were executed for each of the DNA samples as previously described (VA DEQ 2014, Vandersea et al. 2017). For control and standard curve DNA, stocks of each dinoflagellate species were grown, enumerated, and extracted following standard methods (VA DEQ 2014). A probe-based (i.e., TaqMan) assay for $K$. veneficum was performed using the TaqMan Fast Advanced Master Mix (Applied Biosystems, Foster City, CA). SYBR Green-based assays were used for the other organisms with the Fast SYBR Green Master Mix (Applied Biosystems). All assays were run on a 7500 Fast Real-Time PCR system (Applied Biosystems) in Fast 7500 mode with default cycling parameters. Quantification was conducted using the automatic $\mathrm{Ct}$ and baseline settings. Dissociation curve analyses were performed for all SYBR Green assays and the melting temperatures of all positive samples were compared with the control DNA for verification of identity.

\section{Mortality and Growth Metrics}

At each sampling date, for each site and line, dead oysters were removed, counted, and measured. For the first two sampling periods, 15 live oysters, and for the last sampling period, 50 live oysters, were randomly taken for each line and site and measured individually for shell height. Growth was measured as shell height because of its relevance to "market size."

\section{Histopathology}

Oysters returned to the laboratory were measured and shucked. A 5-mm transverse sample of whole oyster tissue was obtained just posterior to the labial palps that included gills and mantle, gonad, stomach, intestine, digestive gland, and associated connective tissues. Samples were fixed in Davidson solution (Shaw \& Battle 1957) for $48 \mathrm{~h}$ and stored in $70 \%$ ethanol until histological processing. Because of limited funding, only sites where typical early summer mortality events were observed were evaluated histopathologically for all sampling dates. Samples that were examined were processed using standard histological methods, with $5-\mu \mathrm{m}$ paraffin sections processed through hematoxylin and eosin staining and evaluation using light microscopy. Slides were evaluated for the presence of Perkinsus marinus, Haplosporidium nelsoni, Haplosporidium costale, and other pathogens or signs of disease. Where observed, parasite infection intensity was rated as rare, light, moderate or heavy following criteria in routine use (Carnegie \& Burreson 2011, Mann et al. 2014). 


\section{Gametogenesis}

Slides prepared for histopathology were also used for evaluating gametogenesis for Nassawadox on April 1, May 19, June 30, and August 19, and from all other sites on during sampling 2 only (June $30-$ July 9). Three metrics were noted on gametogenic development: (1) sex, (2) percent coverage of gonadal area, and (3) stage of gametogenesis. For percent coverage, the crosssectional area of the gonad was estimated as the proportion of that area that could be occupied in a fully mature gonad, extending from the edge of the digestive tubules to the body margin. These estimates were measured subjectively using a microscope by a single observer (S. Allen) on all slides. For the stage of gametogenesis, standard scores included inactive, early active, active, late active, ripe, spawned, and spawned out in accordance with previous studies on diploid oysters (Loosanoff 1942, Kennedy \& Krantz 1982). Gauging the cross-sectional area occupied by the gonad is especially important for staging maturation in triploids, which was performed in accordance with Allen and Downing (1990). For example, gonads at the same stage can differ greatly in the extent of overall follicle proliferation, which is not typically the case in diploid oysters.

\section{Statistics}

Statistical analyses were performed using Systat statistical software (Systat Software, San Jose, CA). Logistic regression, loglinear models, and contingency table analyses were used to examine the mortality data. Factorial analysis of variance was used to examine size data relative to several factors (line, site, and period). An alpha level of $P<0.05$ was considered significant. The terms used during statistical analysis included Status (Dead or Alive), Line (3N DENY, 3N hANA, 3N Northern, and 2N DEBY), Site (Pungoteague Creek, Nassawadox Creek, Cherrystone Creek, Locklies Creek, Milford Haven), and Period (first sampling, second sampling, and final sampling).

\section{RESULTS}

\section{Initial Seed Deployment}

At deployment of seed as juveniles in July 2014, 25 individuals from $2 \mathrm{~N}$ DEBY, 3N DEBY, and 3N hANA were sampled and screened for size, weight, ploidy, and presence of oyster pathogens. Fifty $3 \mathrm{~N}$ northern individual oysters were screened for pathogens. $2 \mathrm{~N}$ DEBY began the study slightly smaller than triploid seed, with an average shell height of $17.7 \pm 4.0 \mathrm{~mm}$ (here and throughout, mean $\pm \mathrm{SD}$ ) (Table 1). The triploid seed were larger, averaging $20.3 \pm 3.1$ and $29 \pm 5.5 \mathrm{~mm}$ for $3 \mathrm{~N}$ hANA and $3 \mathrm{~N}$ DEBY, respectively; $3 \mathrm{~N}$ Northerns were intermediate $(23.0 \pm$ $3.1 \mathrm{~mm}$ ). Ploidy analysis performed on seed at the time of deployment confirmed that 3N DEBY and 3N hANA were $100 \%$ triploid. 3N Northern seed were $98 \%$ triploid. 2N DEBY (controls) were all diploid. Initial disease screening revealed no Perkinsus marinus in any line and a low prevalence of Haplosporidium nelsoni $(6.7 \%)$ in the $3 \mathrm{~N}$ DEBY and $3 \mathrm{~N}$ Northern lines only, with infections rare to light in intensity (Table 1).

\section{Environmental Parameters and Experimental Deployment}

At Locklies Creek, the data logger failed, so an average of the temperature and salinity measured by a local oyster farmer at the site for the last $3 \mathrm{y}$ during the same periods was calculated for
TABLE 1.

Initial screening of oyster seed for size, weight, ploidy, and the pathogens Haplosporidium nelsoni and Perkinsus marinus histopathology at the time of distribution to growers (juvenile deployment) in July 2014.

\begin{tabular}{lcccc}
\hline \hline \multicolumn{1}{c}{ Line } & Length, $\mathbf{m m}(\boldsymbol{n})$ & Ploidy $(\boldsymbol{n})$ & $\boldsymbol{P}$. marinus & H. nelsoni \\
\hline 2N DEBY & $17.7 \pm 4.0(25)$ & 2N $(25 / 25)$ & $0 / 14$ & $0 / 14$ \\
3N DEBY & $29.0 \pm 5.5(25)$ & 3N $(25 / 25)$ & $0 / 15$ & $1 / 15(\mathrm{~L})$ \\
3N hANA & $20.3 \pm 3.1(25)$ & $3 \mathrm{~N}(25 / 25)$ & $0 / 14$ & $0 / 14$ \\
3N Northern & $23.0 \pm 3.1(25)$ & 3N (49/50) & $0 / 15$ & $1 / 15(\mathrm{R})$ \\
\hline
\end{tabular}

For observed H. nelsoni infections, intensity of infection is presented as $\mathrm{R}=$ rare and $\mathrm{L}=$ light .

perspective. At Cherrystone Creek, the logger failed between the first and second period of sampling (June 3, 2015 to June 24, 2015) and no data existed for that site from previous years. Salinities varied narrowly from a mesohaline 13.5 ppt at Locklies Creek to a polyhaline $19.8 \mathrm{ppt}$ at Cherrystone Creek (Table 2). The general temperature trend showed an increase from the first to the last sampling period at all sites. Temperatures ranged from an estimated $12.9^{\circ} \mathrm{C}$ at Locklies Creek during the first sampling period to a $29.2^{\circ} \mathrm{C}$ at Nassawadox Creek in the last sampling period (Table 2).

At experimental deployment between 615 and 2010 oysters per line were deployed at each site (Table 2). During this deployment, in late March and early April 2015, 50 oysters were sampled and had generally similar shell heights within sites, from $56.9 \pm 6.9 \mathrm{~mm}$ for $2 \mathrm{~N}$ DEBY at Locklies Creek to $74.7 \pm 9.8 \mathrm{~mm}$ for $3 \mathrm{~N}$ DEBY at Nassawadox Creek (Table 2). Since the initial deployment of seed in July 2014, growth since deployment had clearly been affected by site conditions across study locations (Table 2).

\section{Mortality}

Mortality observed at the first 2015 sampling (56-64 days after redeployment) ranged from $0.2 \%$ for $2 \mathrm{~N}$ DEBY at Milford Haven to $49.3 \%$ for $2 \mathrm{~N}$ DEBY at Cherrystone Creek (Table 3). By the final sampling (118-144 days post-deployment), cumulative mortality among sites ranged from $3.4 \%$ for $2 \mathrm{~N}$ DEBY at Locklies Creek to $56.5 \%$ for 2N DEBY in Cherrystone Creek. The average highest mortality in the first sampling interval was observed at Cherrystone Creek, during May 20-June 3 (mean 27.7\%). Peak mortalities were observed at Locklies Creek (4.0\%), Milford Haven (6.3\%), Pungoteague Creek (7.2\%), and Nassawadox Creek (17.0\%) in the second interval ending June 25-July 9. For the two western shore sites (Locklies Creek and Milford Haven) and one of the Eastern Shore sites (Pungoteague Creek), at all sampling periods, the $2 \mathrm{~N}$ DEBY line had lower mortality than the $3 \mathrm{~N}$ DEBY (Table 3 ). Mortality between the control and triploids was similar at Nassawadox Creek (Table 3). Cherrystone Creek was the only site where the diploid DEBY line had a higher cumulative mortality at all sampling times, but this may be attributable to the period immediately before the first sampling when mortality in $2 \mathrm{~N}$ DEBY reached $49.3 \%$. That is, mortality at the Cherrystone site provided equivocal results because of artifacts. Across all of the sites among triploid lines, the $3 \mathrm{~N}$ Northern line had the lowest average cumulative mortality with $16.7 \%$, whereas the $3 \mathrm{~N}$ DEBY had the highest with $25.4 \%$ (Fig. 2). Triploids had a higher overall mortality than the 
TABLE 2.

Summary of the key dates for replicated deployment (Spring 2015) and sampling (1, 2, and final), and temperature $\left({ }^{\circ} \mathrm{C}\right)$ and salinity (ppt); and summary of number of oysters tested by line at each site, shell height (SH) of oysters at time of replicated deployment and at final sampling and average growth between these periods.

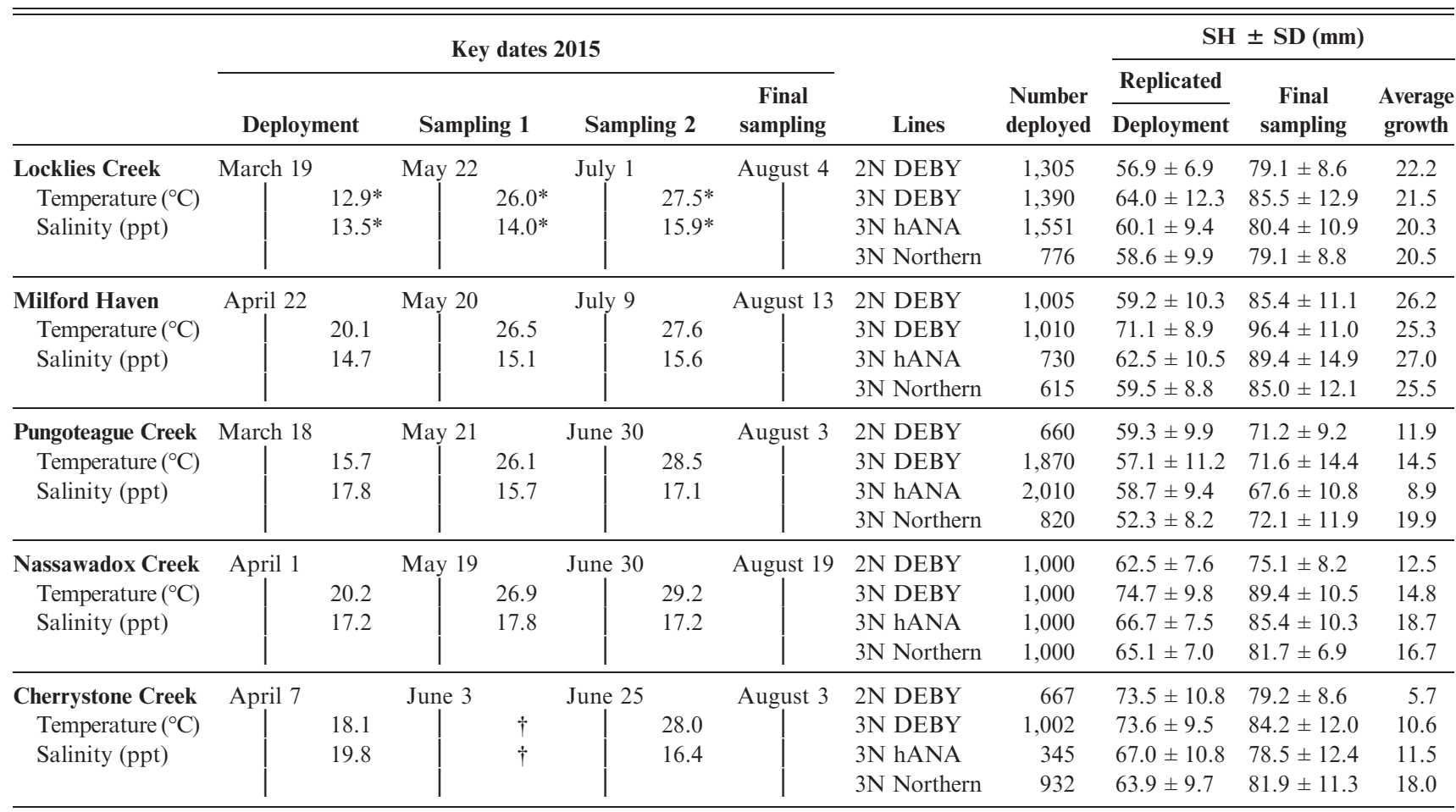

Temperature and salinity are presented as means for the interval between samplings. Sizes (mm) of seed at juvenile deployment in July 2014 were as follows: 2N DEBY, 17.1; 3N DEBY, 29.0; 3N hANA, 20.3; 3N Northern, 23.0. Western bayside: Locklies, Milford Haven; Eastern bayside.

* Average of the last $3 \mathrm{y}$ for the same period.

$\dagger$ Missing data.

diploid control at Locklies Creek, Milford Haven, and Pungoteague Creek.

Geographically, cumulative mortality on the western shore sites (Locklies Creek and Milford Haven) was lower, averaging $9.0 \%$, than the Eastern Shore Bayside sites (Pungoteague, Nassawadox, and Cherrystone Creeks), where it averaged 30.6\%. Among all sites, Locklies Creek had the lowest average mortality (8.8\%); the highest average mortality occurred at Cherrystone Creek (41.3\%) (Table 3, Fig. 2). A logistic regression of cumulative mortalities at the end of the experiment relative to site, line, and sample period revealed that all of the effects and their interactions were significant with $P<0.001$. In other words, cumulative mortality of all lines at each site was highly variable and significantly different, regardless of sampling period.

\section{Final Growth and Performance}

Seed from the various lines used in this study were not spawned at the same time and place. To estimate the performance of each line at each location, an estimation of the growth performance was calculated (Table 2, Fig. 3). Growth was homogeneous among the lines grown at Locklies Creek and Milford Haven, the two western bay sites, with an average total growth of $21.1 \pm$ $0.9 \mathrm{~mm}$ and $26.0 \pm 0.8 \mathrm{~mm}$, respectively. More variation was observed among the Eastern Shore sites with total growth of $13.8 \pm$ $4.6 \mathrm{~mm}, 15.7 \pm 2.6 \mathrm{~mm}$, and $11.4 \pm 5.1 \mathrm{~mm}$ for Pungoteague Creek,
Nassawadox Creek, and Cherrystone Creek, respectively. The wider variation can be explained mainly by smaller average growth of diploid oysters in comparison with triploid oysters at Eastern Shore sites (Table 2). The 2N DEBY grew 2.6, 2.3, and $4.9 \mathrm{~mm}$ less than 3N DEBY in Pungoteague Creek, Nassawadox Creek, and Cherrystone Creek, respectively (Table 2).

\section{Size, Alive versus Dead}

The average size of live oysters $(75.9 \mathrm{~mm})$ was larger than dead oysters $(64.0 \mathrm{~mm})$ (Figs. 4 and 5), and all of the effects and their interactions were significant, except for the following interactions: status by line by site by period $(P=0.288)$, status by line by period $(P=0.135)$, and line by period $(P=0.849)$. In other words, for each line at each site, the difference between the size of live and dead oysters was significant and there was no shift in the average size of dead oysters across sampling periods.

\section{Sampling for Harmful Algae}

Dinoflagellates Alexandrium spp. were not observed visually or detected by qPCR in any water samples. Dinoflagellates Margalefidinium polykrikoides were detected in only three water samples. All of these were samples from the Eastern Shore and the concentrations were less than $1 \mathrm{cell} / \mathrm{mL}$ in those samples. The HAB species most frequently observed in water samples 
TABLE 3.

Interval and cumulative mortality (\%) for sites and lines over project period.

\begin{tabular}{|c|c|c|c|c|c|c|}
\hline & \multirow{2}{*}{$\frac{\text { May 20-June } 3}{\text { Interval }}$} & \multicolumn{2}{|c|}{ June 25-July 9} & \multicolumn{2}{|c|}{ August 3-August 21} & \multirow[b]{2}{*}{ 3N Mean } \\
\hline & & Interval & Cumulative & Interval & Cumulative & \\
\hline \multicolumn{7}{|l|}{ Locklies Creek } \\
\hline 2N DEBY & 0.8 & 1.8 & 2.6 & 0.8 & 3.4 & \multirow{4}{*}{10.6} \\
\hline 3N DEBY & 5.8 & 8.2 & 14.0 & 2.0 & 16.0 & \\
\hline 3N hANA & 2.6 & 3.8 & 6.4 & 2.4 & 8.8 & \\
\hline $3 \mathrm{~N}$ Northern & 3.5 & 2.3 & 5.8 & 1.3 & 7.1 & \\
\hline Average & 3.2 & 4.0 & 7.2 & 1.6 & 8.8 & \\
\hline \multicolumn{7}{|l|}{ Milford Haven } \\
\hline 2N DEBY & 0.2 & 4.4 & 4.6 & 1.2 & 5.8 & \multirow{4}{*}{10.3} \\
\hline 3N DEBY & 3.2 & 9.3 & 12.5 & 1.9 & 14.4 & \\
\hline 3N hANA & 0.5 & 5.3 & 5.8 & 0.6 & 6.4 & \\
\hline $3 \mathrm{~N}$ Northern & 3.4 & 6.4 & 9.8 & 0.4 & 10.2 & \\
\hline Average & 1.8 & 6.3 & 8.1 & 1.1 & 9.2 & \\
\hline \multicolumn{7}{|l|}{ Pungoteague Creek } \\
\hline 2N DEBY & 2.9 & 4.5 & 7.4 & 5.3 & 12.7 & \multirow{4}{*}{20.6} \\
\hline 3N DEBY & 9.8 & 8.3 & 18.1 & 4.0 & 22.1 & \\
\hline 3N hANA & 9.3 & 10.3 & 19.6 & 5.3 & 24.9 & \\
\hline $3 \mathrm{~N}$ Northern & 4.4 & 5.6 & 10.0 & 4.8 & 14.8 & \\
\hline Average & 6.6 & 7.2 & 13.8 & 4.8 & 18.6 & \\
\hline \multicolumn{7}{|l|}{ Nassawadox Creek } \\
\hline 2N DEBY & 8.2 & 21.7 & 29.9 & 4.7 & 34.6 & \multirow{4}{*}{32.0} \\
\hline 3N DEBY & 12.9 & 17.8 & 30.7 & 1.9 & 32.6 & \\
\hline 3N hANA & 21.8 & 19.7 & 41.5 & 2.4 & 43.9 & \\
\hline $3 N$ Northern & 4.9 & 9.1 & 14.0 & 2.4 & 16.4 & \\
\hline Average & 12.0 & 17.0 & 29.0 & 2.9 & 31.9 & \\
\hline \multicolumn{7}{|l|}{ Cherrystone Creek } \\
\hline 2N DEBY & 49.3 & 4.7 & 54.0 & 2.5 & 56.5 & \multirow{4}{*}{36.3} \\
\hline 3N DEBY & 24.5 & 12.2 & 36.7 & 5.4 & 42.1 & \\
\hline 3N hANA & 21.7 & 6.4 & 28.1 & 3.8 & 31.9 & \\
\hline $3 \mathrm{~N}$ Northern & 15.3 & 13.1 & 28.4 & 6.5 & 34.9 & \\
\hline Average & 27.7 & 9.1 & 36.8 & 4.5 & 41.3 & \\
\hline
\end{tabular}

Italic values represent interval mortality. Bold values represent averaged values.

were Karlodinium veneficum and Prorocentrum minimum; however, the cell counts both visually and by qPCR were usually low (i.e., $<100$ cells $/ \mathrm{mL}$ ). The highest concentration of $P$. minimum was 254 cells $/ \mathrm{mL}$ in a water sample collected on April 23 from Locklies Creek. Five water samples, two from Locklies Creek and one each from Cherrystone Creek, Nassawadox Creek, and Milford Haven, had concentrations of $K$. veneficum greater than 1,000 cells $/ \mathrm{mL}$. The highest concentrations were 3,024 cells $/ \mathrm{mL}$ in a Milford Haven sample collected on May 20 and 2,970 cells/ $\mathrm{mL}$ from Locklies Creek on May 22.

\section{Histopathology}

The oyster seed was in generally good health at the start of the experiment, with a low observed prevalence $(\leq 7 \%)$ and intensity of Haplosporidium nelsoni. Only samples from Nassawadox Creek were processed for histopathology because it was most likely that triploid mortality would be evident there, based on previous years. Among the samples from the four 2015 collection dates, Perkinsus marinus prevalences were generally low. The pathogen was not detected in April 1 or May 19 samples, and was observed in just $1 / 15$ oysters from one line $(3 \mathrm{~N}$
Northern) on June 30 (albeit a moderate-heavy infection), in 1/ 15 oysters from the $3 \mathrm{~N}$ hANA line (a heavy infection), and 4/15 oysters from the $2 \mathrm{~N}$ DEBY line (two moderate, one light and one rare infection) on August 19. Infections of Haplosporidium

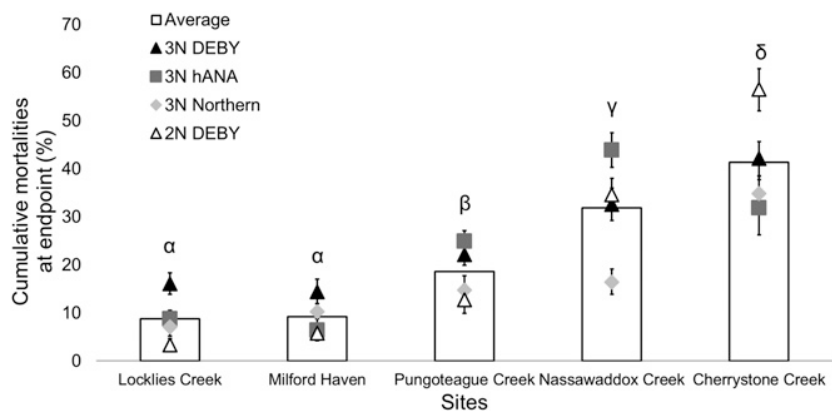

Figure 2. Cumulative mortalities (\%) observed at endpoint. Each symbol represent a line (3n DEBY, 3n hANA, 3N Northern, and 2N DEBY). Errors bars depict confidence intervals at $95 \%$. The column is an average of all the lines at the site. Different letters indicate a significant difference between averaged cumulative mortalities at the sites tested (loglinear model, Chi-square, $P<0.015)$. Sample sizes were greater than 8,000 per line. 
Triploid Mortalities of CRassostrea VIRGINICA IN Virginia

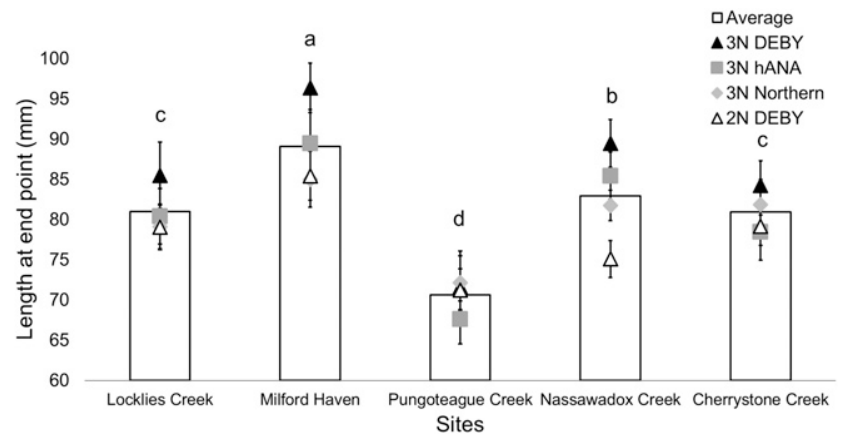

Figure 3. Length (mm) of live oyster shells at endpoint. Each symbol represent a line (3n DEBY, 3n hANA, 3N Northern, and 2N DEBY). Errors bars depict confidence intervals at $95 \%$. The column is an average of all the lines at the site. Different letters indicate a significant difference between lines as tested by factorial analysis of variance $(F=80.555, P<0.001)$.

nelsoni were observed in April (in 2/15, 4/15, and 1/15 oysters from the $3 \mathrm{~N}$ hANA, $3 \mathrm{~N}$ DEBY, and $3 \mathrm{~N}$ Northern lines, respectively) and again in August (6/15 from 3N hANA, 1/15 from 3N DEBY, 3/15 from 3N Northern, and 3/15 from $2 \mathrm{~N}$ DEBY). Many of these infections were of low intensity, but there were exceptions. All four infections in 3N DEBY in April were moderate in intensity, as were August infections in one $3 \mathrm{~N}$
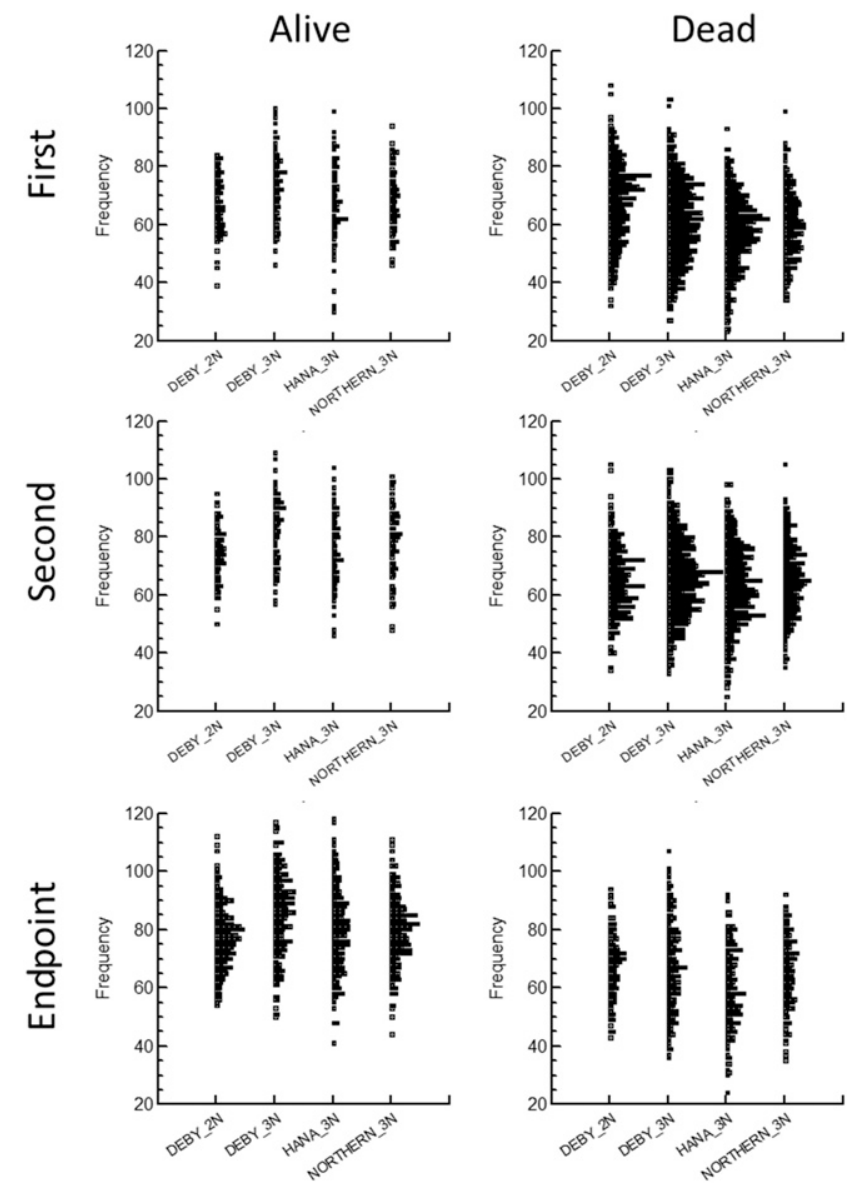

Figure 4. Size-frequency plots for all lines with all sites pooled shown over different sampling periods. All dead oysters were measured at each sampling, but 25-30 live oysters were measured at each sampling except the endpoint when all oysters were sampled. The three rows represent each sampling period.
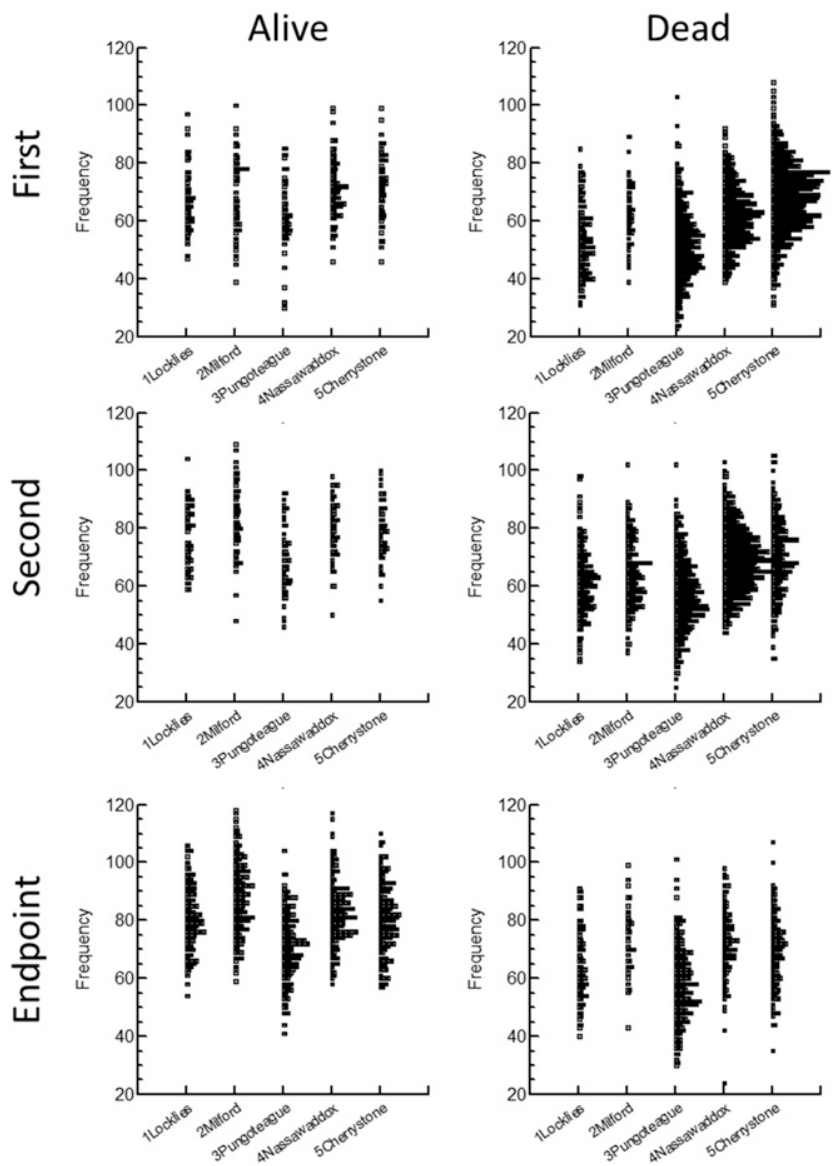

Figure 5. Size-frequency plots for all sites with all lines pooled shown over different sampling periods. All dead oysters were measured at each sampling, but 25-30 live oysters were measured at each sampling except the endpoint when all oysters were sampled. The three rows represent each sampling period.

hANA oyster and one 2N DEBY. Besides the presence of $H$. nelsoni, the most notable pathological observation was the infiltration of elevated numbers of hemocytes (i.e., hemocytosis), most often to the gills, in samples from all lines in the months of May and June (Fig. 6). The peak prevalence of this condition across lines ranged from $20 \%$ in 3 N DEBY (May) and $27 \%$ in $3 \mathrm{~N}$ Northerns (May and June) to $33 \%$ in $3 \mathrm{~N}$ hANA s (May) and $2 \mathrm{~N}$ DEBY (May). In one case, the hemocytosis was associated with erosion of gill epithelium, and gut epithelial disruption or erosion was additionally observed, primarily in May and June, in all lines at prevalences of $7 \%-13 \%$. There were no obvious pathogens associated with these conditions.

As indicated previously, samples were not processed for all dates for sites other than Nassawadox Creek, but Cherrystone Creek samples were processed for the April 7 and June 3 collections to gain insight into possible causes of the unusual mortality there. Infections of Perkinsus marinus were not detected in any line at either date, and hemocytosis at the gills as noted previously was only observed in a single $2 \mathrm{~N}$ DEBY oyster, in June. Infections of Haplosporidium nelsoni were common, however, occurring in $2 / 153 \mathrm{~N}$ hANA (one heavy infection), 6/153N DEBY (one moderate, three heavy), 4/15 3N Northern, and 1/15 2N DEBY oysters (one moderate) in April; 


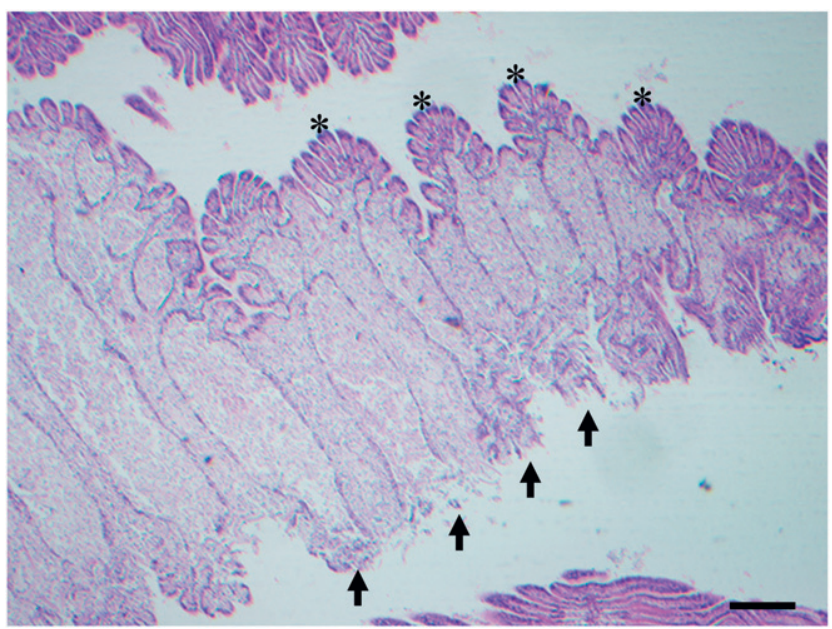

Figure 6. Characteristic gill pathology associated with some oyster populations displaying mortality. Note that although some plicae on the upper illustrated gill lamellum remain intact (asterisks), many plicae on the bottom lamellum have been eroded and lost (arrows), and the areas between these lamella are entirely filled with infiltrating hemocytes and necrotic debris. Scale bar $=200$ microns.

and 2/15 3N hANA (both heavy), 6/15 3N DEBY (one moderate, two heavy), 5/15 $3 \mathrm{~N}$ Northern (one moderate, two heavy), and 1/13 2N DEBY oysters (heavy) in June.

\section{Gametogenesis}

A full description of the ontogeny of gametogenesis in triploid Crassostrea virginica is beyond the scope of this investigation. What follows is a general description for triploids and a compilation of the comparison in development between diploids and triploids at all sites from the late June sampling period.

Seasonal samples (April, May, June, and August) were prepared for one of the putative triploid mortality sites: Nassawadox Creek. Early stages of gametogenesis were similar in both diploid and triploid Crassostrea virginica in April reaching a stage of "early active," characterized by development of follicles branching throughout the connective tissue. Follicle walls were beginning to thicken with gonial cells. Determination of sex at these early stages was based on patterns of early differentiation of the gonial cells, indicating male or (putative) female gonads. Of the 58 individuals sampled, 57 were at the "early active" stage (Table 4).

By May at Nassawadox Creek, significant gonad production was evident in both diploids and triploids. Diploids had reached late active or ripe stages (Table 4), whereas the most advanced stage in triploids was late active, the majority holding in the active stage. In diploids, late active follicles are characterized by significant follicle development that occupies, typically, nearly all the interstitial space ( $94 \%$ gonad cover, Table 4$)$. In males, there is a heavy population of spermatocytes maturing along the follicle wall with more advanced stages of spermatids and sometimes spermatozoa in the follicle lumen. In females in the late active stage, oogonia have matured into developing or completely developed oocytes.

Triploid gametogenesis in May at Nassawadox Creek was delayed, as evidenced by percent gonad area $(55 \%-60 \%$ compared with $94 \%$ in diploids) and reproductive stage (predominantly active). Of the 44 triploids sampled, 31 were in the active stage. The principal difference in gamete maturity between diploid and triploid follicles was the lower frequency of mature cells. For females, this manifested as a thickening of follicle walls with what appeared to be gonial cell proliferation that was uncharacteristic in the diploid state. Few of these gonial cells seemed to be going through maturation. For diploids, typical mitotic proliferation of spermatogonia was apparent and these cells were clearly differentiating into primary spermatocytes; however, unlike in diploids, most of the primary spermatocytes in triploids were not maturing further.

In the June 30 samples, comparisons between diploid and triploid gametogenesis were possible among all sites. At Nassawadox Creek, diploids were not much more advanced in gametogenesis than in mid-May, with some evidence of spawning. At Cherrystone Creek, most diploids were ripe with about $25 \%$ of the samples still in early gametogenesis. At all other sites, diploids were far along, either ripe/spawned or spawned out. Gametogenesis in triploids was retarded compared with diploids at all sites. Gametes in the late active triploids (male or female) were at essentially the same level of maturity as the active stage, with the major difference being further development of the extent of gonad coverage (for example, from an average of $56 \%$ in May to $72 \%$ in late June at Nassawadox Creek-Table 4).

Beginning with the June samples, the cross-sectional gonad area of the triploids was higher than that of diploids, where significant spawning activity had begun (all sites except Nassawadox Creek).

For Locklies Creek in late June, most diploids sampled had spawned or were spawned out, and this condition was reflected in the cross-sectional area occupied by the diploid gonad $(46 \%)$. For triploids, the percent gonad area was $83 \%$ on average, reflecting the relatively advanced stage of gonad maturity. The majority of triploids (26/44) were in late active stage, and, notably, 13 of 44 were categorized as "ripe"; however, "ripe" in triploids is a relative term because this simply represents the culmination of maturity that triploids attain. The condition of the gametes in a ripe triploid male is largely immature, with mostly primary spermatocytes, variable but minority proportions of secondary spermatocytes/spermatids, and rare populations of spermatozoa. For ripe triploid females, follicle walls thickly lined with gonial cells seldom contain a ripe ovum or two, although on occasion follicles may contain numerous, but never normal numbers of, ova.

A final workup of samples in August was performed at Nassawadox Creek only. At this time, the diploids were spent, with 12 of 15 in the spawned out condition. Comparatively, triploids were in conditions ranging from inactive to spawned out. Notably, the percent gonad area in triploids was more than 5-fold higher than in diploids at this time because of the retardation and stasis of gonads in triploids throughout the season. Clearly, although not all triploid gonads remained static in the semi-advanced stages of gametogenesis. Evidence of early active and active gonads suggests that the gonads may have begun to recycle by August, which seemed particularly true for $3 \mathrm{~N}$ hANA and $3 \mathrm{~N}$ Northerns, in which most gonad condition was active.

Sex ratio between diploid and triploid groups did not vary notably except for August at Nassawadox where $40 \%$ of diploids and an average of $67 \%$ of triploids were female. Otherwise, females were in the majority (Table 4). 
TABLE 4.

Stages of gametogenesis, percent female, and percent gonad cover in diploid and triploid Crassostrea virginica in triploid mortality sampling from Nassawadox Creek (April, May, June, and August); Locklies Creek, Milford Haven, Pungoteague Creek, and Cherrystone Creek (June).

\begin{tabular}{|c|c|c|c|c|c|c|c|c|c|c|}
\hline & & \multicolumn{6}{|c|}{ Stage gametogenesis } & \multirow[b]{2}{*}{$\% \mathrm{~F}$} & \multicolumn{2}{|c|}{$\%$ cover } \\
\hline & & IA & EA & $\mathbf{A}$ & LA & $\mathrm{R} / \mathrm{SP}$ & SO & & Group & $3 n$ mean \\
\hline & Nassawadox Cre & & & & & & & & & \\
\hline \multirow[t]{4}{*}{ April 1} & 2N DEBY & - & 15 & - & - & - & - & 79 & 35 & \\
\hline & 3N DEBY & 1 & 14 & - & - & - & - & 73 & 16 & \\
\hline & 3N hANA & - & 13 & - & - & - & - & 62 & 18 & 18.3 \\
\hline & $3 \mathrm{~N}$ Northern & - & 15 & - & - & - & - & 67 & 21 & \\
\hline \multirow[t]{4}{*}{ May 19} & 2N DEBY & - & - & - & 10 & 5 & - & 80 & 94 & \\
\hline & 3N DEBY & - & 1 & 13 & - & - & - & 80 & 60 & \\
\hline & $3 \mathrm{~N}$ hANA & - & 3 & 10 & 2 & - & - & 71 & 53 & 56.0 \\
\hline & $3 \mathrm{~N}$ Northern & - & 5 & 8 & 2 & - & - & 62 & 55 & \\
\hline \multirow[t]{24}{*}{ June 25-July 9} & 2N DEBY & - & - & 2 & 8 & 2 & - & 54 & 80 & \\
\hline & 3N DEBY & - & 1 & 2 & 12 & - & - & 73 & 71 & \\
\hline & $3 \mathrm{~N}$ hANA & - & 3 & 2 & 8 & - & - & 67 & 74 & 72.3 \\
\hline & $3 \mathrm{~N}$ Northern & - & - & 6 & 9 & - & - & 86 & 72 & \\
\hline & Locklies Creek & & & & & & & & & \\
\hline & 2N DEBY & - & - & - & - & 6 & 9 & 69 & 46 & \\
\hline & 3N DEBY & - & - & 1 & 11 & 3 & - & 67 & 88 & \\
\hline & $3 \mathrm{~N}$ hANA & - & - & 1 & 7 & 6 & - & 60 & 86 & 82.7 \\
\hline & $3 \mathrm{~N}$ Northern & - & 2 & 1 & 8 & 4 & - & 60 & 74 & \\
\hline & Milford Haven & & & & & & & & & \\
\hline & 2N DEBY & - & - & - & - & 5 & 10 & 43 & 32 & \\
\hline & 3N DEBY & 1 & 4 & 3 & 6 & 1 & - & 79 & 57 & \\
\hline & $3 \mathrm{~N}$ hANA & - & 5 & 6 & 2 & 2 & - & 60 & 52 & 59.0 \\
\hline & $3 \mathrm{~N}$ Northern & - & 3 & 7 & 4 & 1 & - & 73 & 68 & \\
\hline & Pungoteague Cre & & & & & & & & & \\
\hline & 2N DEBY & - & - & - & 2 & - & 12 & 33 & 27 & \\
\hline & 3N DEBY & - & 5 & - & 1 & 6 & 3 & 46 & 43 & \\
\hline & $3 \mathrm{~N}$ hANA & - & 5 & 7 & 1 & 1 & - & 83 & 51 & 49.3 \\
\hline & $3 \mathrm{~N}$ Northern & 1 & 6 & 3 & 1 & 3 & - & 75 & 54 & \\
\hline & Cherrystone Cre & & & & & & & & & \\
\hline & 2N DEBY & - & 2 & 2 & 2 & 9 & - & 40 & 53.3 & \\
\hline & 3N DEBY & - & 5 & 9 & - & 1 & - & 85 & 65 & \\
\hline & 3N hANA & - & 5 & 9 & 1 & - & - & 67 & 63 & 60.3 \\
\hline & $3 \mathrm{~N}$ Northern & 2 & 7 & 5 & 1 & - & - & 69 & 53 & \\
\hline \multirow[t]{5}{*}{ August 1} & Nassawadox Cre & & & & & & & & & \\
\hline & 2N DEBY & - & - & - & - & 3 & 12 & 45 & 9 & \\
\hline & 3N DEBY & - & 2 & 3 & 10 & - & - & 43 & 71 & \\
\hline & 3N hANA & 1 & 8 & 2 & 3 & 1 & - & 71 & 50 & 53.7 \\
\hline & $3 \mathrm{~N}$ Northern & 2 & 9 & 1 & - & - & 3 & 63 & 40 & \\
\hline
\end{tabular}

Stages of gametogenesis: IA, inactive; EA, early active; A, active; LA, late active; R/SP, ripe and/or spawning; SO, spawned out. \%F, percent female. \% cover is the proportion of available gonadal area covered by follicle proliferation. Bold values represent percent coverage for either diploid group or the averaged of triploid groups.

\section{DISCUSSION}

This study provided new insight into "triploid mortality" in cultured Crassostrea virginica in the mid-Atlantic, a growing concern for the oyster aquaculture industry. It did not, however, highlight a clear principal cause. Among the major factors tested-western shore versus Eastern Shore of the Chesapeake Bay, diploids versus triploids, and specific triploid constructs- only geography seemed clearly relevant in the current analysis, with average cumulative mortality reaching levels two to three times higher at the eastern than at western Chesapeake Bay sites. At least at some sites, substantial mortality occurred from spring into early summer and it was not associated with the activity of major pathogens such as Perkinsus marinus or Haplosporidium nelsoni, or any other obvious agent. Oysters in Nassawadox Creek displayed the "signature" mortality pattern expected, with 
interval mortality averaged across oyster lines rising from $12.0 \%$ in the April to May interval to $17.0 \%$ in June before falling to $2.9 \%$ in July. The cumulative mortality of $31.9 \%$ through the summer period at Nassawadox Creek aligned well with industry estimates of early summer mortality in most recent years.

Interestingly, even at other sites where mortality was not high enough to trigger sampling, mortality was observed to peak, albeit subtly, during the June 25-July 9 interval. At Locklies Creek, Milford Haven, and Pungoteague Creek, interval mortality rose from mean values within individual lines of $3.2 \%, 1.8 \%$, and $6.6 \%$ in the May 20-June 3 sampling interval, to $4.0 \%, 6.3 \%$, and $7.2 \%$ from June 25 to July 9, before falling again to $1.6 \%, 1.1 \%$, and $4.8 \%$ from August 3 to 21, respectively. Cherrystone Creek was the exception but also an aberration, with very high mortality having occurred there, but with no obvious explanation, before the first 2015 sampling in all groups but especially the 2N DEBY. Even at Cherrystone Creek, however, mean mortality across all lines declined from $9.1 \%$ from June 25 to July 9 to $4.5 \%$ from August 3 to 21, suggesting that here too the oysters emerged by late summer from an early summer health challenge, whatever its cause. What could be causing this rise in early summer mortality and particularly the geographic pattern that this study and the industry reports that preceded it have revealed?

Environmental factors such as temperature and salinity are known to strongly influence oyster performance (Shumway 1996). Temperatures were similar at all study sites by the middle of May 2015 and remained so through August 2015. What differed among the sites, however, is how temperature varied in early spring. For example, in the western portion of the Bay, spring temperatures in Locklies Creek averaged $12.9^{\circ} \mathrm{C}$, whereas those at Milford Haven hovered around $20.1^{\circ} \mathrm{C}$. On the Eastern Shore, the mean in spring water temperature at Pungoteague Creek was $15.7^{\circ} \mathrm{C}$, whereas that at Nassawadox Creek was $20.2^{\circ} \mathrm{C}$. Although higher mortality was observed at the relatively warm Nassawadox Creek site and at Cherrystone Creek, it was not observed at the warm Milford Haven site. No clear link between mortality and temperature as a single factor can therefore be established.

Salinity varied within a $2-3$ ppt range at each site, and was somewhat higher at the Eastern Shore sites (15.7-19.8 ppt) - where mortality tended to be higher - than at Locklies Creek and Milford Haven on the western shore (13.5-15.9 ppt). These were minor differences, however, for organisms accustomed to widely varying estuarine salinities; all of these salinities were within the range that adult eastern oysters are known to tolerate, which is from under five to more than $30 \mathrm{ppt}$ (Galtsoff 1964). Moreover, salinities were generally similar between more strongly and more lightly mortalityaffected sites, i.e., Nassawadox Creek and Pungoteague Creek. Thus, as for temperature, no clear link between mortality and salinity can be established.

Harmful algae did not appear to be associated with mortality either. On the eastern and western shores of the bay, the presence of Karlodinium veneficum peaked at the end of May and early June with the highest observed concentrations of 2,699 cells $/ \mathrm{mL}$ in Nassawadox Creek and 3,024 cells/mL in Milford Haven. Although Stoecker et al. (2008) demonstrated that K. veneficum can cause around $70 \%$ mortality within $24 \mathrm{~h}$ in eastern oyster larvae and embryos, this was at a concentration of 20,000 cells $/ \mathrm{mL}$, i.e., much higher than that observed in this study. Both Alexandrium monilatum and Margalefidinium polykrikoides can also have harmful effects on shellfish (Tang \& Gobler 2009, May et al. 2010, Reece et al. 2012); however neither was found at concentrations greater than $1 \mathrm{cell} / \mathrm{mL}$ during this study. Concentrations of Prorocentrum minimum were generally very low with the highest concentrations found in late April and May. Although several studies have demonstrated a detrimental impact of $P$. minimum on Crassostrea virginica health and growth (Luckenbach et al. 1993, Wikfors \& Smolowitz 1995), their concentrations were more than 10 times higher than 254 cells $/ \mathrm{mL}$, the highest concentration in samples analyzed here. Furthermore, no other harmful algal species were observed. Therefore, no link could be made between the algal species identified and quantified and oyster mortality during this study at these sites.

Although monitoring of temperature, salinity, and harmful algal species provided no insight into individual environmental factors potentially contributing to mortality, these factors by no means represent an exhaustive list of potential stressors. Extensive French research on "summer mortality" in Crassostrea gigas, for example, found that "pluviometric risks" (freshwater inputs and the substances they carry, including anthropogenic toxicants), "trophic risks" (including quantitatively high levels of chlorophyll $a$ even when not associated with harmful algal blooms), and "sedimentary risks" (particularly oyster exposure to reduced organic compounds diffusing from the benthos) encompassed suites of environmental stressors potentially contributing to oyster mortality (Ropert et al. 2008). The hemocytosis and disruption to gill and other epithelial tissues that was observed histopathologically, although not associated with the presence of any particular pathogen, does suggest that among this suite of potential environmental stressors may be one that is meaningful with regard to the mortality observations. No clear perspective as yet, however, on potential contributions of these and other environmental factors to "triploid mortality" of oysters in the Chesapeake Bay has been established.

To what extent might the mortality reflect something inherent in the oysters themselves, for example their genetic heritage, their ploidy, or their physiology? Critical evaluation of the suggestion that $3 \mathrm{~N}$ Northerns were more susceptible to mortality was part of the motivation for this project, and the results presented here were unambiguous in not supporting this assertion. The $3 \mathrm{~N}$ Northerns, on average, were the triploid construct with the lowest mortality across sites. It was not clear which construct tended to die more than others, but the general tendency was that cumulative mortality was highest in $3 \mathrm{~N}$ DEBY. Higher cumulative mortality in $3 \mathrm{~N}$ DEBY was observed at two sites, the two western shore locations. 3N DEBY also had the highest mortality among triploids at Cherrystone Creek. 3N hANA had the highest mortality among triploids at Pungoteague and Nassawadox Creeks. As this was an opportunistic experiment and lines were spawned in different hatcheries at different times, the design was not ideal for resolving performance differences among genetic lineages. Nonetheless, the results suggest that genetic differences in interactions with the environment at different locations could be meaningful with regard to patterns of mortality, as has been observed elsewhere in analyses of Crassostrea gigas challenged with summer mortality (Beattie et al. 1980, Boudry et al. 2008). This is clearly an area that deserves further attention.

Perspective into mortality differences between triploids and diploids is primarily drawn from the relative performance of $2 \mathrm{~N}$ and $3 \mathrm{~N}$ DEBY deployed at each site. Although the $3 \mathrm{~N}$ DEBY did not display greater mortality at the most acutely affected site, Nassawadox Creek (or at Cherrystone Creek, where the $2 \mathrm{~N}$ DEBY displayed high early mortality), mortality was higher in $3 \mathrm{~N}$ 
DEBY at Pungoteague Creek, Milford Haven, and Locklies Creek. In general, triploids also did not display the superiority in growth rate over diploids that would be expected, based on earlier work (Callam et al. 2016), at mesohaline to polyhaline sites such as these. One might ask whether a subacute environmental stress at Pungoteague Creek, Milford Haven, and Locklies Creek influenced oyster performance at these sites, such that triploid oysters were more adversely affected than diploids. Other studies have also shown higher mortality of triploids compared with diploid oysters (Dégremont et al. 2012), and the results presented here too suggest that triploid oysters might be subject to higher mortalities than diploids in some locations, especially in the lower part of the Chesapeake Bay. This runs somewhat counter to established thinking regarding "summer mortality" based on work with Crassostrea gigas in France, which holds that the energetic costs of gametogenesis in diploid oysters are sufficiently high that any additional stressors may tip them over the edge to mortality, which does tend to occur coincident with peak gametogenesis in these animals (Lambert et al. 2008). Triploid oysters, on the other hand, "have very reduced reproductive development, which confers a good resistance to summer mortalities (Samain \& McCombie 2008)." Nonetheless, Samain and McCombie (2008) noted anecdotally that during the very warm year of 2003, "certain batches of triploids reached an advanced state of reproduction and some suffered mortalities in a similar way to diploids." This raises the question of whether the degree of triploid gametogenesis and reproduction may influence susceptibility to mortality - a question into which this study provides some insight with regard to the Chesapeake Bay situation in particular.

Triploid Crassostrea virginica in this study displayed what has become understood as typical patterns of retarded gametogenesis for oysters (Lee 1988, Allen \& Downing 1990, Jouaux et al. 2010), although there is likely considerable variance according to the species, method of triploid production (induced versus mated), and environment conditions (Jouaux et al. 2013). Among the test sites, triploids advanced to a late active stage by the end of June, whereas diploids were mostly ripe or spawned out. Gonad development in diploids and triploid $C$. virginica was consistently different. Most notably, gonads in triploids always culminated in a less mature state than the gonads in diploids. The "ripe" stage in triploids, which represented the observed culmination in gonad development for triploids in this study, consisted of gonads with mostly primary spermatocytes in males and typically few oocytes in females. These findings are similar to previous histological observations of triploid C. virginica (Lee 1988, Barber \& Mann 1991), which found that triploid females typically only produce few oocytes and triploid males typically do not produce spermatozoa.

Gonad development did not provide clear evidence to explain differential mortality during the spring. Triploid lines from Nassawadox Creek had comparable fecundity, sex ratio, stage of gametogenesis, and follicle coverage during the spring despite substantial interline variation in mortality by June $(14 \%$ in Northern to $42 \%$ in hANA). Fecundity also did not vary noticeably among triploids based on site. One conspicuous difference among sites, however, was that diploids at Nassawadox Creek appeared to have delayed or only partial spawning in June compared with diploids at other sites. This was notable because mortality in late spring was much higher in diploids at Nassawadox Creek than all other sites; however, it is not evident whether delayed or partial gametogenesis in the diploids could be related to the mortalities.
The nature of the follicle coverage in triploids is different in male and female Crassostrea virginica. In males, much of the size of the gonad was caused by the proliferation of primary spermatocytes, which, as in this study, often appeared to proceed uninhibited in triploid oysters (Lee 1988, Allen \& Downing 1990, Cox et al. 1996). Follicle coverage has been observed to reach comparable levels in male diploid and triploid $C$. virginica (Lee 1988) and Crassostrea gigas (Allen \& Downing 1990), despite the fact that triploids contain few to no spermatozoa. For females, follicle coverage mostly consisted of thick follicle walls formed by an accumulation of gonial cells. Persistence (Normand et al. 2008) or accumulation (Jouaux et al. 2010) of gonial cells has also been reported in triploid C. gigas. The gonia cells may be arrested in development and similar to those described in C. gigas by Allen and Downing (1990) and Jouaux et al. (2010).

Percent follicle area for triploid Crassostrea virginica paralleled that in diploids early in the year until after spawning, when coverage for the triploids was consistently higher than for the diploids. For sterile animals, the residual follicle area in late summer was notable. By summer, mean follicle area in triploids sometimes exceeded $80 \%$. Residual follicles in triploids are undoubtedly attributable to the fact that triploids make few gametes and therefore have few to spawn. Retarded gamete development in other triploid oysters is common (Crassostrea gigas, Allen \& Downing 1990, Jouaux et al. 2010; Saccostrea commercialis, Cox et al. 1996). The physiological effect of residual gametogenic tissue (largely immature gametes cells) late into the season is unknown, but also not clearly associated with mortality in late spring.

Finally, although anecdotal reports suggest that the fastest growing portion of triploid production, i.e., those oysters nearing or at market size, were primarily affected by mortality (Hudson, personal communication), results from this study did not bear this out. The size frequencies of dead oysters tended to be smaller than that of live oysters, suggesting that, within lines, mortality affected oysters of all sizes equally. Physiology can play a strong role in mortality events, including the nutritional status of animals in the population (Pernet et al. 2010, 2012, 2014), but no insight was gained here beyond what could be obtained through histological evaluation of reproductive status.

\section{CONCLUSION}

This study provides the first documentation of summer mortality in eastern oysters Crassostrea virginica in the Chesapeake Bay region unrelated to obvious effects of major parasitic diseases. There is no clear relationship of this mortality to oyster genetic heritage, although there is variability among oyster lines in susceptibility and interactions of lines with specific sites. Triploid oysters at some locations may be more susceptible to mortality. Mortality does occur coincident with the timing of peak gametogenic development. Given the lack of involvement by major pathogens such as Haplosporidium nelsoni and Perkinsus marinus and the possible association of mortality with oyster gametogenesis, future work should seek to better understand the suite of environmental stressors potentially impacting aquacultured oysters and their interactions with the physiology and energetics of these animals.

\section{ACKNOWLEDGMENTS}

The authors thank the following VIMS associates for their assistance with this analysis: Rita Crocket for the histological analysis; Kate M. Ritter for flow cytometry; William M. Jones, 
Stephanie Bonniwell, Alanna MacIntyre, and Gail Scott for microscopic and molecular analyses of HAB species; and Jeff Shields for statistical analyses and editorial suggestions. Support was provided by the Virginia Fishery Resource Grant
Program and the VIMS Foundation A. Marshall Acuff, Sr., Memorial Endowment for Oyster Disease Research. This is contribution No. 3806 of the Virginia Institute of Marine Science, College of William \& Mary.

\section{LITERATURE CITED}

Allen, Jr., S. K. \& D. Bushek. 1992. Large-scale production of triploid oysters, Crassostrea virginica (Gmelin), using "stripped" gametes. Aquaculture 103:241-251.

Allen, Jr., S. K. \& S. L. Downing. 1986. Performance of triploid Pacific oysters, Crassostrea gigas (Thunberg). I. Survival, growth, glycogen content, and sexual maturation in yearlings. J. Exp. Mar. Biol. Ecol. 102:197-208.

Allen, Jr., S. K. \& S. L. Downing. 1990. Performance of triploid Pacific oysters, Crassostrea gigas: gametogenesis. Can. J. Fish. Aquat. Sci. 47:1213-1222.

Andrews, J. D. 1988. Epizootiology of the disease caused by the pathogen Perkinsus marinus and its effects on the oyster industry. In Disease processes in marine bivalve molluscs. Bethesda, MD: American Fisheries Society Special. pp. 47-63.

Barber, B. J. \& R. Mann. 1991. Sterile triploid Crassostrea virginica (Gmelin, 1791) grow faster than diploids but are equally susceptible to Perkinsus marinus. J. Shellfish Res. 10:445-450.

Beattie, J. H., K. K. Chew \& W. K. Hershberger. 1980. Differential survival of selected strains of Pacific oysters (Crassostrea gigas) during summer mortality. Proc. Natl. Shellfish. Assoc. 70:184-189.

Boettcher, K. J., B. J. Barber \& J. T. Singer. 1999. Use of antibacterial agents to elucidate the etiology of juvenile oyster disease (JOD) in Crassostrea virginica and numerical dominance of an $\alpha$-proteobacterium in JOD-affected animals. Appl. Environ. Microbiol. 65:2534-2539.

Boettcher, K. J., K. K. Geaghan, A. P. Maloy \& B. J. Barber. 2005. Roseovarius crassostreae sp. nov., a member of the Roseobacter clade and the apparent cause of juvenile oyster disease (JOD) in cultured eastern oysters. Int. J. Syst. Evol. Microbiol. 55:1531-1537.

Boudry, P., L. Dégremont \& P. Haffray. 2008. The genetic basis of summer mortality in Pacific oyster spat and potential for improving survival by selective breeding in France. In: Samain, J.-F. \& H. McCombie, editors. Summer mortality of Pacific oyster Crassostrea Gigas: the Morest Project. Versailles, France: Quae Editions. pp. 153-196.

Brooks, W. K. 1891. The oyster: a popular summary of a scientific study. Baltimore, MD: The Johns Hopkins Press. pp. 145-197.

Callam, B. R., S. K. Allen \& A. Frank-Lawale. 2016. Genetic and environmental influence on triploid Crassostrea virginica grown in Chesapeake Bay: growth. Aquaculture 452:97-106.

Carnegie, R. \& E. Burreson. 2011. Declining impact of an introduced pathogen: Haplosporidium nelsoni in the oyster Crassostrea virginica in Chesapeake Bay. Mar. Ecol. Prog. Ser. 432:1-15.

Cheney, D. P., B. F. MacDonald \& R. A. Elston. 2000. Summer mortality of Pacific oysters, Crassostrea gigas (Thunberg): initial findings on multiple environmental stressors in Puget Sound, Washington, 1998. J. Shellfish Res. 19:353-359.

Cox, E. S., M. S. R. Smith, J. A. Nell \& G. B. Maguire. 1996. Studies on triploid oysters in Australia. VI. Gonad development in diploid and triploid Sydney rock oysters Saccostrea commercialis (Iredale and Roughley). J. Exp. Mar. Biol. Ecol. 197:101-120.

Dégremont, L., C. Garcia \& S. K. Allen, Jr. 2015. Genetic improvement for disease resistance in oysters: a review. J. Invertebr. Pathol. 131:226-241.

Dégremont, L., C. Garcia, A. Frank-Lawale \& S. K. Allen, Jr. 2012. Triploid oysters in the Chesapeake Bay: comparison of diploid and triploid Crassostrea virginica. J. Shellfish Res. 31:21-31.

Frank-Lawale, A., S. K. Allen, Jr. \& L. Dégremont. 2014. Breeding and domestication of eastern oyster (Crassostrea virginica) lines for culture in the Mid-Atlantic, USA: line development and mass selection for disease resistance. J. Shellfish Res. 33:153-165.

Galtsoff, P. S. 1964. The American oyster Crassostrea virginica Gmelin. Fish. Bull. U.S. Govt. Print. Off. Wash. 64:397-446.

Garnier-Géré, P. H., Y. Naciri-Graven, S. Bougrier, A. Magoulas, M. Héral, G. Kotoulas, A. Hawkins \& A. Gérard. 2002. Influences of triploidy, parentage and genetic diversity on growth of the Pacific oyster Crassostrea gigas reared in contrasting natural environments. Mol. Ecol. 11:1499-1514.

Goulletquer, P., J.-P. Joly, A. Gérard, E. Le Gagneur, J. Moriceau, J.-M. Peignon, S. Heurtebise \& P. Phelipot. 1996. Performance of triploid Pacific oysters Crassostrea gigas (Thunberg) reared in high carrying capacity ecosystem: survival, growth and proximate biochemical composition. Haliotis 25:1-12.

Haskin, H. H., L. A. Stauber \& J. A. Mackin. 1966. Minchinia nelsoni n. sp. (Haplosporida, Haplosporidiidae): causative agent of the Delaware Bay oyster epizootic. Science 153:1414-1416.

Haven, D. S., W. J. Hargis, Jr. \& P. C. Kendall. 1978. The oyster industry of Virginia: its status, problems and promise. VIMS Spec. Pap. Mar. Sci.

Hawkins, A. J., A. Magoulas, M. Héral, S. Bougrier, Y. Naciri-Graven, A. J. Day \& G. Kotoulas. 2000. Separate effects of triploidy, parentage and genomic diversity upon feeding behaviour, metabolic efficiency and net energy balance in the Pacific oyster Crassostrea gigas. Genet. Res. 76:273-284.

Hudson, K. 2017. Virginia shellfish aquaculture situation and outlook report. Results of the 2016 Virginia Shellfish Aquaculture Crop Reporting Survey. Sea Grant Marine Advisory Service. Gloucester Point, VA: Virginia Sea Grant Marine Extension Program Virginia Institute of Marine Science. pp. 1-20.

Hudson, K. \& T. Murray. 2016. Virginia shellfish aquaculture situation and outlook report. Results of the 2015 Virginia shellfish aquaculture crop reporting survey. Sea Grant Marine Advisory Service. Gloucester Point, VA: Virginia Sea Grant Marine Extension Program Virginia Institute of Marine Science. pp. 1-20.

Jouaux, A., J. L. Blin, B. Adeline, C. Heude-Berthelin, P. Sourdaine, M. Mathieu \& K. Kellner. 2013. Impact of energy storage strategies on gametogenesis and reproductive effort in diploid and triploid Pacific oysters Crassostrea gigas - involvement of insulin signaling. Aquaculture 388-391:173-181.

Jouaux, A., C. Heude-Berthelin, P. Sourdaine, M. Mathieu \& K. Kellner. 2010. Gametogenic stages in triploid oysters Crassostrea gigas: irregular locking of gonial proliferation and subsequent reproductive effort. J. Exp. Mar. Biol. Ecol. 395:162-170.

Kennedy, V. S. \& L. B. Krantz. 1982. Comparative gametogenic and spawning patterns of the oyster Crassostrea virginica (Gmelin) in central Chesapeake Bay. J. Shellfish Res. 22:133-140.

Lambert, C., J. Moal, G. Le Moullac \& S. Pouvreau. 2008. Mortality risks associated with physiological traits of oysters during reproduction. In: Summer mortality of Pacific oyster Crassostrea Gigas: the Morest Project. Versailles, France: Quae Edition. pp. 63-106.

Lee, M. M. 1988. Abnormal gametogenesis in triploid American oysters Crassostrea virginica. J. Shellfish Res. 7:202.

Loosanoff, V. L. 1942. Shell movements of the edible mussel, Mytilus edulis (L.) in relation to temperature. Ecology 23:231-234.

Luckenbach, M. W., K. G. Sellner, S. E. Shumway \& K. Greene. 1993. Effects of two bloom-forming dinoflagellates, Prorocentrum minimum 
and Gyrodinium uncatenum, on the growth and survival of the eastern oyster, Crassostrea virginica (Gmelin, 1791). J. Shellfish Res. 12: 411-415.

Mackin, J. G., H. M. Owen \& A. Collier. 1950. Preliminary note on the occurrence of a new protistan parasite, Dermocystidium marinum $\mathrm{n}$. sp. in Crassostrea virginica (Gmelin). Science 111:328-329.

Mann, R., M. Southworth, R. B. Carnegie \& R. K. Crockett. 2014. Temporal variation in fecundity and spawning in the eastern oyster, Crassostrea virginica, in the Piankatank River, Virginia. J. Shellfish Res. 33:167-176.

May, S. P., J. M. Burkholder, S. E. Shumway, H. Hégaret, G. H. Wikfors \& D. Frank. 2010. Effects of the toxic dinoflagellate Alexandrium monilatum on survival, grazing and behavioral response of three ecologically important bivalve molluscs. Harmful Algae 9:281-293.

Nell, J. A. 2002. Farming triploid oysters. Aquaculture 210:69-88.

Nell, J. A. \& G. B. Maguire. 1998. Commercialisation of triploid Sydney rock and Pacific oysters. In: Part 1: Sydney rock oysters. Final report to Fisheries Research and Development Corporation. Report No. 10, NSW Fisheries, Port Stephens Research Centre, Taylors Beach, NSW. 121 pp.

Normand, J., M. Le Pennec \& P. Boudry. 2008. Comparative histological study of gametogenesis in diploid and triploid Pacific oysters (Crassostrea gigas) reared in an estuarine farming site in France during the 2003 heatwave. Aquaculture 282:124-129.

Pernet, F., J. Barret, P. Le Gall, C. Corporeau, L. Dégremont, F. Lagarde, J. Pépin \& N. Keck. 2012. Mass mortalities of Pacific oysters Crassostrea gigas reflect infectious diseases and vary with farming practices in the Mediterranean Thau lagoon, France. Aquacult. Environ. Interact. 2:215-237.

Pernet, F., J. Barret, C. Marty, J. Moal, P. Le Gall \& P. Boudry. 2010. Environmental anomalies, energetic reserves and fatty acid modifications in oysters coincide with an exceptional mortality event. Mar. Ecol. Prog. Ser. 401:129-146.

Pernet, F., F. Lagarde, N. Jeannée, G. Daigle, J. Barret, P. L. Gall, C. Quéré \& E. R. D'orbcastel. 2014. Spatial and temporal dynamics of mass mortalities in oysters is influenced by energetic reserves and food quality. PLoS One 9:e88469.

Ragone Calvo, L. M., G. W. Calvo \& E. M. Burreson. 2003. Dual disease resistance in a selectively bred eastern oyster, Crassostrea virginica, strain tested in Chesapeake Bay. Aquaculture 220:69-87.

Reece, K. S., W. K. Vogelbein, R. B. Carnegie \& T. Harris. 2012. Assessing the impacts of emerging harmful algal bloom species on shellfish restoration and aquaculture in Chesapeake Bay. Gloucester Point, VA: Sea Grant. pp. 1-14.
Ropert, M., J. Mazurié, E. Bédier, F. Le Coz \& P. Soletchnik. 2008. Evaluation of summer mortality risk factors in shellfish farming ecosystems. In: Samain, J.-F. \& H. McCombie, editors. Summer mortality of Pacific oyster Crassostrea Gigas: the Morest Project. Versailles, France: Quae Edition. pp. 1-61.

Samain, J.-F. \& H. McCombie. 2008. Summer mortality of Pacific oyster Crassostrea gigas: the Morest Project. Versailles, France: Quae Editions.

Sanford, W. E., J. P. Pope \& D. L. Nelms. 2009. Simulation of groundwater-level and salinity changes in the eastern shore, Virginia. U.S. Geological Survey Scientific Investigations Report 2009. Denver, CO: US Geological Survey. p. 26.

Shaw, B. L. \& H. I. Battle. 1957. The gross and microscopic anatomy of the digestive tract of the oyster Crassostrea virginica (Gmelin). Can. J. Zool. 35:325-347.

Shumway, S. E. 1996. Natural environmental factors. In: Kennedy, V. S., R. I. E. Newell \& A. F. Eble, editors. The eastern oyster, Crassostrea Virginica, Chapter 13. College Park, MD: Maryland Sea Grant College. pp. 467-513.

Stanley, J. G., S. K. Allen, Jr. \& H. Hidu. 1981. Polyploidy induced in the American oyster, Crassostrea virginica, with cytochalasin B. Aquaculture 23:1-10.

Stoecker, D. K., J. E. Adolf, A. R. Place, P. M. Glibert \& D. W. Meritt. 2008. Effects of the dinoflagellates Karlodinium veneficum and Prorocentrum minimum on early life history stages of the eastern oyster (Crassostrea virginica). Mar. Biol. 154:81-90.

Tang, Y. Z. \& C. J. Gobler. 2009. Cochlodinium polykrikoides blooms and clonal isolates from the northwest Atlantic coast cause rapid mortality in larvae of multiple bivalve species. Mar. Biol. 156:2601-2611.

VA DEQ. 2014. Quality Assurance Project Plan (QAPP) for James River Chlorophyll-a Study: Special Study \#14098.

Vandersea, M. W., S. R. Kibler, S. B. Van Sant, P. A. Tester, K. Sullivan, G. Eckert, C. Cammarata, K. Reece, G. Scott, A. Place, K. Holderied, D. Hondolero \& R. W. Litaker. 2017. qPCR assays for Alexandrium fundyense and $A$. ostenfeldii (Dinophyceae) identified from Alaskan waters and a review of species-specific Alexandrium molecular assays. Phycologia 56:303-320.

Wikfors, G. H. \& R. M. Smolowitz. 1995. Experimental and histological studies of four life-history stages of the eastern oyster, Crassostrea virginica, exposed to a cultured strain of the dinoflagellate Prorocentrum minimum. Biol. Bull. 188:313-328.

Wood, J. L. \& J. D. Andrews. 1962. Haplosporidium costale (Sporozoa) associated with a disease of Virginia oysters. Science 136:710-711. 